\title{
TRUSTING AN ABUSIVE SYSTEM: SYSTEMIC RACISM AND BLACK POLITICAL ENGAGEMENT
}

\author{
Matthew Simmons \\ Temple University
}

Black political participation has been long argued as an avenue for equality and freedom for Blacks in American society. However, Africana contemporary political leadership has pushed the political arena as the sole avenue to affect change in society on a large-scale. This method of engagement, this project will argue, has rendered political progress stagnant because it relies upon a system that is rooted in systemic racism. The folly of believing that the system cares about Africana issues will be explored in this project, as well as some solutions to this abusive engagement. This article will also explore the shortcomings of this theory in empowering Africana people in the fight for liberation in this country and provide exploratory solutions to obtain that liberation. Let it be reiterated that this project is an exploratory examination of this phenomenon which utilizes Feagin's theory of Systemic Racism, which will be explored at length in the following pages. The first part of the project will examine the relevance of Systemic Racism to this project.

\section{Relevance of Systemic Racism}

The theory of Systemic Racism, conceptualized by Joe Feagin, forms the theoretical thrust of this article. Feagin articulated that "systemic racism includes a diverse assortment of racist practices: the unjustly gained economic and political power of whites; the continuing resource inequality; the rationalizing white-racist frame; and the major institutions created to preserve white privilege and power." Feagin argues that America has racism emanating from all directions in an attempt to maintain White privilege and perpetually subjugate people of color. The American political system, from its inception, built its contemporary economic and political influence upon the subjugation of people of color while justifying that racism through its authoritative rhetoric.

Feagin based this premise upon the racist origins of the United States Constitution. He argues that while most Americans believe that this document was created to solidify the emerging country's unity, it

1 Feagin, Joe R. Racist America: Roots, Current Realities, and Future Reparations. (New York: Routledge. Second Edition, 2010), 9. 
was actually created to maintain racial separation and oppression at the time and for the near future. ${ }^{2} \mathrm{He}$ further argues that the institution of the enslavement of Africans in America was allowed because the framers of the United States Constitution had a vested interest in the vitality of what Paulo Freire calls the "dehumanization" of the oppressed. ${ }^{3}$ The United States Constitution's framers had to take the humanity from the Africans in order to justify their suppression. This country's freedom depended on the enslavement of Africans and other groups of color in order to maintain White rule.

This treatment continued to manifest itself throughout American history. After the end of slavery after the American Civil War, new systems of political and social oppression against Blacks were implemented in order to maintain the White order. Examples of these institutions were the Black Codes, which were a series of legislation implemented by exconfederate states to limit and control the movements of free Blacks; Jim Crow as it pertains to literacy tests, poll taxes, and White mob rule over Blacks; and finally the challenging and ending of Jim Crow with the passing of the 1964 Civil Rights Act and the 1965 Voting Rights Act. ${ }^{4}$ Blacks were able to fight the oppression of White rule through the utilization of the American judicial and political systems, thus making inroads into what some would call "progress" within that socio-economic and socio-political sphere.

Therefore, when Blacks utilized these various forms of American political participation, most notably voting political representation into public office, they did so with the hope that their interests would be understood, heeded, and implemented. They hoped that their economic issues, in regards to impoverishment and educational funding, would be recognized. Blacks employed the apparatus of the American political system in hopes that Africana communal matters would be addressed. However, if Feagin's theory of Systemic Racism is applied, then the community concerns of Africana people would never be realized due to the inherent racism that is in that system. The tenet that will be utilized to examine the impotence of solely relying upon Black engagement with the American political system lies in the "extraordinary costs and burdens of racism." ${ }^{5}$ This tenet articulates the extreme affliction that Afri-

2 Ibid, 6.

3 Freire, Paulo. Pedagogy of the Oppressed. (London, Penguin Books, 1970), 26.

4 W.E.B. Du Bois goes into depth of the ramifications of the Black Codes upon the Black community in his book Black Reconstruction in America: 1860-1880, (New York, The Free Press, 1935), 171-180. Other publications look at the Black Codes on individual state level such as Dan Moore and Michele Mitchell's Black Codes in Georgia, (Atlanta: The Apex Museum, 2006) and Joe M. Richardson's "Florida Black Codes" in the Florida Historical Quarterly, (Vol. 47, No. 4, 1969,), 365-379.

5 Feagin, 19-23. 
cana people endure in order to exist in America. However, it is the argument of this article that this tenet also speaks to the extraordinary dilemma that Blacks have to endure: how to converse with a political system that does not have the interests of the Africana community in mind. This article will also utilize the works of Ronald Walters and contemporary data to bolster the argument that the utilization of the American political system, in itself, is a defeatist avenue and that other mechanisms must be employed in order to benefit and ensure the vitality and survival of Africana people in America. The next section will explore the findings of Ronald Walters and the Black America voting populace.

\section{Systemic Racism and Black Politics}

The shortcomings of Africana people relying solely upon the American political system will be explored in this section. This article will be relying upon the various publications of Ronald Walters and the assessments of other people of Africana descent to argue that the systemic racism that exists within the American political system will continue to generate the racial inequalities that have existed since Blacks were forcibly placed in America. The reliance upon the oppressor's tools will never generate liberation for the oppressed. Freire articulated that the pedagogy of the oppressed cannot be generated by the ones doing the oppressing. ${ }^{6}$

The protection of Black voter enfranchisement in the United States lies in the 1965 Voting Rights Act. This piece of legislation was considered the "crown jewel" of Black political achievement because it gave federal protection and oversight over states that historically disenfranchised African Americans for trying to utilize the voting mechanism in order to have representatives in the political realm to push their needs on the national, state, and local stages while simultaneously bolstering the Fifteenth Amendment that gave Black men the right to vote during Reconstruction. ${ }^{7}$ This act had enormous effects on the local political landscape. It exponentially raised Black political representation directly after the passage of the 1965 Voting Rights Act. Some states had about a 45 percent increase of Black officials by 1985 and by the year 2000, there were states that yielded the largest number of Black elected officials where they had the least participation pre-Voting Rights Act. ${ }^{8}$ There was also an enormous increase in local officials when comparing Black elected officials in 1970 to those in 2002. There were 1,469 elected

6 Freire, 36.

7 Walters, Ronald. Freedom is Not Enough: Black Voters, Black Candidates, and American Presidential Politics. (Lanham: Rowman \& Littlefield Publishers, 2005), 14.

8 Walters, 19. 
Black officials in local, state, and national offices in 1970 while in 2002 there were 9,040 Black elected officials. ${ }^{9}$ That represented a little over two percent of all elected officials in the nation. Africana grievances cannot be heard with such representation in political offices.

However, has that increased representation yielded better results for the Black community as a whole in contemporary times? It is the stance of this article that is has benefited individuals within the Black community but not the entire Africana community. Ronald Walters contended that Black America still has a ways to go in order to achieve equality in America. He based his findings upon the 2004 Index of Inequality report that stated that Blacks lagged significantly behind their White counterparts in the areas of economics, home ownership, life expectancy, educational opportunities, and social justice. ${ }^{10}$ According to a 2013 Washington Post report, these contemporary conditions are comparable with the poverty, educational opportunities, and other issues that the Africana community faced in the 1960s. ${ }^{11}$ These conditions are still prevalent in the Black community today according to the 2014 report that was released by the National Urban League. However, it articulated that Black political engagement is strong. 73 percent of the African-American community is registered to vote and 66 percent of those voters voted in 2012. ${ }^{12}$ Therefore, if the economic and social conditions of Africana people have not improved, why does the Africana community continue to vote?

Ronald Walters explored this relationship in his book Pan Africanism in the African Diaspora: An Analysis of Modern Afrocentric Political Movements (1993). He juxtaposed the two traditions of conversing with the American political system: 1) the accommodationist tradition and 2) the resistance tradition. Ronald Walters describes the position of the accommodationist tradition: "The accommodationist tradition, to be sure, arises because of the existence of men who compromise the goal of race advancement for their private ends, and also because good men feel that political objectives may be achieved through cooperation and coalition with those who control the instruments of policy."13 Ronald articulates the issue with the inherent problematic concern with the utilization of

9 Walters, 22.

10 Walters, 23.

11 Plumer, Brad, "These Ten Charts Show the Black-White Economic Gap Hasn't Budged in Fifty Years." The Washington Post. August 28, 2013. Accessed March 1, 2014. http://www.washingtonpost.com/blogs/wonkblog/wp/2013/08/28/these-seven-charts-show-theblack-white-economic-gap-hasnt-budged-in-50-years/

12 National Urban League. One Nation, Underemployed, Jobs Rebuild America: 2014 State of Black America. (U.S.A: National Urban League, 2014), 39.

13 Walters, Ronald. Pan-Africanism in the African Diaspora: An Analysis of Modern Afrocentric Political Movements. (Detroit: Wayne State University Press, 1993), 221. 
voting to secure freedom from oppression: that race advancement is controlled by the individuals who directly benefit from being in power. Carter G. Woodson also articulated this sentiment: "It is unfortunate, too, that such a large number of Negroes do not know any better than to stake their whole fortune on politics. History does not show that any race, especially a minority group, has every solved an important problem by relying altogether on one thing, certainly not by parking its political strength on one side of the fence because of empty promises." 14 The individuals who are in the United States Congress are not economically representative of the Africana constituency. At least half of individuals who are in congressional positions are individuals who are worth at least one million dollars. ${ }^{15}$ According to the Congressional Black Caucus, there are currently forty-three Black members of Congress: forty-one members in the House of Representatives and two members in the Senate. ${ }^{16}$ There are four hundred thirty-five (435) members in the House of Representatives and one hundred (100) members in the Senate. Therefore, the make-up of that Congressional body is not conducive to push the concerns of Africana people.

The executive branch is an interesting study of the relationship between Africana people and the power that the position entails. Even though President Barack Obama is in the most powerful position in the world, he is not able to directly address the policies that most affect Africana people. This position is argued in Harris' book The Price of the Ticket (2012). He argued that the President's neutral political agenda and the Africana community's needs are not on the same page. He articulated this position in the following statement:

The vision of independent black politics-which places community issues above all else-would have predicted that the rise in black political empowerment, symbolized by the election of Obama as president, would produce more substantive policy outcomes for black America. That having a Black president, a Black attorney general (Eric Holder) and a Black chairman of the house Judiciary Committee (John Conyers, when the Democrats were in the majority during the first two years of the Obama's presidency, has not resulted in any major re-

14 Woodson, Carter G. Mis-Education of the Negro. (Tribeca Books, 1933), 65.

15 Choma, Russ. "Half of Congress Members are Millionaires." Washington Post, Jan 9, 2014. https://www.opensecrets.org/news/2014/01/millionaires-club-for-first-time-mostlawmakers-are-worth-1-million-plus/

16 Congressional Black Caucus. "Congressional Black Caucus Online”. 2014 (Accessed Dec. 2, 2014). The Congressional Black Caucus has primarily been Democratic members. The 113th Black congressional members have forty-two Democratic members and one Republican member. This will change when the new Congress convenes in January 2015. 
form in the criminal justice system shows the substantive limits of black politics at the peak of "empowerment."17

Harris further argues that other constituents, such as the Tea Party and the Gay/Lesbian Movements, have been able to make avenues towards issues that fit their interests. The Africana community cannot make headway to get the issue of mass incarceration, which disproportionately affects Black and Latino men, effectively addressed by the President. ${ }^{18}$ Additionally, the 1965 Voting Rights Act was recently weakened by the Shelby v. Holder Supreme Court case, which deemed the formula for federal government oversight over states and districts with a long history of political disenfranchisement of Africana people unconstitutional. ${ }^{19}$ This gave the opportunity for those states and municipalities to pass voter identification laws that have been empirically proven to disproportionally affect people of color. ${ }^{20}$

This all speaks to the systemic racism that is in the American political system. Feagin speaks about the political advantages that Whites are able to access in contemporary times. Feagin argues that today's political system often does little to implement real democracy in its operations at state, local and the federal level. ${ }^{21}$ It continues to operate for the benefit of those who gain the most from it: well-off White individuals, while disregarding Africana people. The system is maintained because of the inherent day-to-day decisions that are unconsciously made by those in power to maintain that power. This is the crux of Systemic Racism. The next section will delve into the shortcomings of this theory as a way of exploring this social phenomenon.

\section{Shortcomings of Systemic Racism/Solutions}

Systemic Racism, as a theory, adequately explains the inherent flaws of Africana people trusting the same system that oppresses its constituents in order to remedy its social and economic woes. However, the solutions that it poses are wanting. Feagin argued that in order to fix the systemic racism that is inherent in the current American system, the current constitution must be removed, a new constitutional convention must

17 Harris, Fredrick C. Harris. The Price of the Ticket: Barack Obama and the Rise and Decline of Black Politics. (Oxford: Oxford University Press, 2012), 175.

18 Alexander, Michelle. The New Jim Crow: Mass Incarceration in the Age of Colorblindness. (New York: The New Press, 2012).

19 Shelby v. Holder, 570 (United States Supreme Court, June 23, 2013).

20 See Timothy Vercellotti \& David Anderson. "Voter-Identification Requirements and the Learning Curve.

PS, Political Science and Politics. 42.1 Jan 2009, p 117-120; Matt A. Barreto, Stephen A Nuno, and Gabriel S Sanchez. "The Disproportionate Impact of Voter-ID Requirement on the Electorate: New Evidence from Indiana." PS, Political Science and Politics, 2009: 111-116.

21 Feagin, 197. 
be called, and representatives from all ethnic and racial groups must be present to structure that new constitution. ${ }^{22}$ That is a good start; however, it would still have groups of people who benefited from the "prior" political system who have historically displayed a tendency to maintain their power by any means necessary. And as Freire has argued, the oppressor will never give their position of domination and having is a condition of being. ${ }^{23}$ Therefore, that option will never come into fruition.

Another shortcoming with this theory is that even though it does talk about the centrality of Black Nationalism to the vitality of Black people, it does not address the need for a cultural centering and a discovery of agency within the Black people. Asante argued for the need for this to occur in the Africana community in order to achieve liberation for Africana people. ${ }^{24}$ Marimba Ani also articulated this centering in the African Worldview rather than the Eurocentric ideology. ${ }^{25}$ The African Worldview is important to the survival of Africana people because it is the foundational piece of their identity. Franz Fanon spoke about this identity crisis in terms of language. He argued this point below:

All colonized people-in other words, people in whom an inferiority complex has taken root, whose local cultural originality has been committed to the grave- position themselves in relation to the civilizing language; i.e., the metropolitan culture. The more colonized has assimilated the cultural values of the metropolis, the more he will have escaped the bush. The more he rejects his blackness and the bush, the whiter he will become. In the colonial army, and particularly in the regiments of Senegalese soldiers, the "native" officers are mainly the interpreters. They serve to convey to their fellow soldiers the master's orders, and they themselves enjoy a certain status. ${ }^{26}$

He articulated that Africana people who assume the dominant culture render those people void of their home culture and makes them assimilate within the colonizer's culture. The same argument can be made about Africana participation with the notion that the American political system can effectively address the concerns of the community. Assimilation into the American political system renders the Africana cultural values inert because it is believed that the colonizer's culture is their culture

22 Feagin, 284-289.

23 Freire, 40.

24 Asante, Molefi K. The Afrocentric Manifesto. (Cambridge: Polity Press: 2007).

25 Ani, Marimba. Let the Circle Be Unbroken. (New York: Nkonimfo Publications, 1980).

26 Fanon, Franz. Black Skin, White Mask. (New York: Grove Press, 1952), 2-3. 
when this society was not made for them to be participants, but only subjects.

The solutions must come on a multitude of fronts. First, Africana people must strategize in order to be on one accord. As Kwame Ture articulated, "Before a group can enter the open society, it must first close ranks." 27 Africana people also must be aware of how the American political system functions and have a place at the political table, but politics must play a part of that strategy, but not the only one. Coalitions based on interests should be explored, but not by political parties. Also, strategic outside agitation not connected to the political system should also be employed in order to get the short-term goals achieved. However, keep in mind that political, economic, physical land autonomy, and armed resistance may be avenues that Africana people need to consider in order to operate from a position of strength rather than a position of dis-agency. These can be considerations in addition to just solely relying upon the American political system for the fulfillment of Africana interests.

\section{ConClusion}

This project is just an exploratory one that looks at the role of Black politics and its relevance in contemporary times. Africana people have resisted the oppressive tendencies of this nation and its European counterparts since the conceptualization of the use of racial biases in order to enact a racialized society based upon domination. This project is geared towards identifying contemporary solutions that plague Africana people and provide solutions to those issues by Africana people. The solutions are not easy to come by, but as Freire stated, "The oppressed must be their own example in the struggle for their redemption." 28 That is the role of this project and that is the role of an Africana Studies scholar.

\section{BiBLIOGRAPHY}

Alexander, Michelle. The New Jim Crow: Mass Incarceration in the Age of Colorblindness. New York: The New Press, 2012.

Ani, Marimba. Let the Circle Be Unbroken. New York: Nkonimfo Publications, 1980. Asante, Molelfi K. An Afrocentric Manifesto. Cambridge: Polity Press, 2007.

Bois, W.E.B Du. Black Reconstruction in American: 1860-1880. New York: Free Press, 1935.

27 Ture, Kwame. Black Power: The Politics of Liberation. (New York: Random House, 1967), 44.

28 Freire, 36. 
Caucus, Congressional Black. Congressional Black Caucus Online. 2014. (accessed December 2, 2014).

Choma, Russ. "Half of Congress Members are Millionaires." Washington Post. January 9, 2014. https://www.opensecrets.org/news/2014/ 01/millionaires-club-for-first-time-most-lawmakers-are-worth-1million-plus/ (accessed December 9, 2014).

Fanon, Franz. Black Skin, White Masks. New York: Grove Press, 1952.

Feagin, Joe R. Racist America: Roots, Current Realities, and Future Reparations. New York: Routledge, 2010.

Freire, Paulo. Pedagogy of the Oppressed. London: Penguin Books, 1970.

Harris, Fredrick C. The Price of the Ticket: Barack Obama and the Rise and Decline of Black Politics. Oxford: Oxford University Press, 2012.

National Urban League. One Nation, Underemployed, Jobs Rebuid America: 2014 State of Black America. U.S.A: National Urban League, 2014.

Plumer, Brad. "These Ten Charts Show the Black-White Economic Gap Hasn't Budged in Fifty Years." Washington Post. August 28, 2013. http://www.washingtonpost.com/blogs/wonkblog/wp/2013/08/28/ these-seven-charts-show-the-black-white-economic-gap-hasntbudged-in-50-years/ (accessed December 1, 2014).

Shelby v. Holder. 570 (U.S. Supreme Court, June 23, 2013).

Ture, Kwame. Black Power: The Politics of Liberation. New York: Random House, 1967.

Walters, Ronald. Freedom is Not Enough: Black Voters, Black Candidates and American Presidential Politics. Lanham: Rowman \& Littlefield Publishers, 2005.

- Pan Africanism in the African Diaspora: An Analysis of Modern Afrocentric Political Movements. Detroit: Wayne State University Press, 1993.

Woodson, Carter G. Mis-Education of the Negro. Tribeca Books, 1933. 